\title{
Of caregivers and captains
}

\author{
A Hard Chance - Sailing into the Heart \\ of Love \\ Tom Gallant \\ Pottersfield Press; 2005 \\ 223 pp \$19.95 ISBN 1-895900-68-9
}

V

eteran broadcast journalist Tom Gallant begins this book with the stark confession: "She almost died. If she had, my life would have been easier."

Drawing on his experiences of sailing, Gallant chronicles the stormy weather (hard chance in nautical terms) of his life both before and after a car accident in 1992 that left his wife Melissa severely disabled.

The author writes with unflinching honesty about the immense pressures that he faced as husband and caregiver to his wife, the extensive rehabilitation and adjustment Melissa Gallant faced, evolving collaborations with medical staff and changing relationships with friends and family.

Gallant's honesty in recounting his personal experience with home-based caregiving is very relevant, considering the number of reports coming from within and without our health care system regarding our aging population and its various attendant illnesses. $\mathrm{He}$ doesn't allow self-pity, and his inward analysis is always balanced with his observations of how others react to N Melissa and participate in her rehabilitation.

Gallant balances the remembered present of the accident and its aftermath with adventurous passages of his pre-accident life with Melissa on their schooner, Avenger. The rolling rhythm

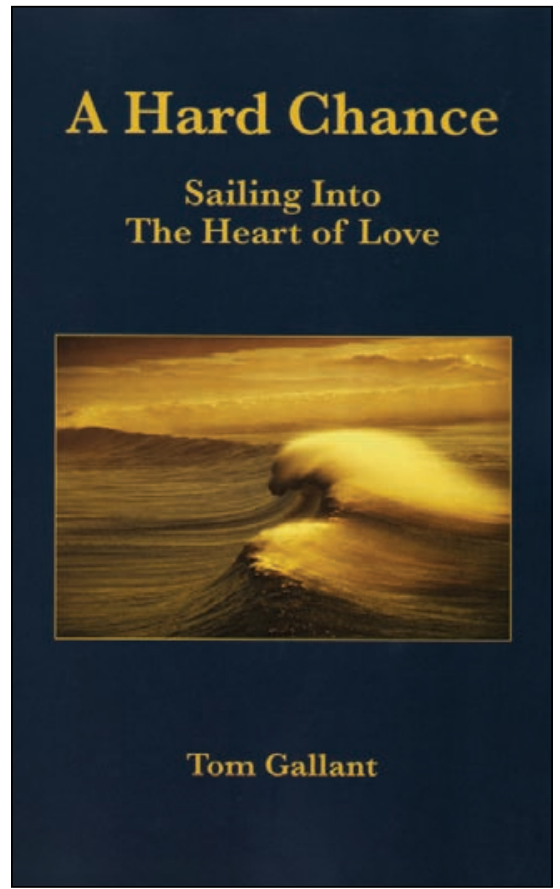

between the carefree days sailing deep water for most of the year and the arduous work of getting Melissa out of hospital and back home works well. Soon the two sides start reflecting each other. Being captain and caregiver come with similar rushes, victories, failures, anxieties and joys. As captain and husband-caregiver, Gallant must rely on his instincts and knowledge, and realize that he is not alone on the journey. In order to not have the burden of decisions crush them, he and his wife must be strong, confident and independent people.

Readers meet Melissa Gallant in full. Here is a spirited, smart and humourous person who remains steadfastly herself, from the time she wakes up from a long coma, through all stages of her recovery. Readers never forget this is a whole person, after as well as before the accident

In one passage, Melissa, having just regained consciousness, is asked how she's feeling by a doctor. "I' $m$ all $f^{\star \star \star}$ ed up," she replies. The shock at first makes you laugh along with the couple. Then you see her reply as plain honesty, the simple recognition of the beginning point of her own journey, much like the author's admission that his life would have been easier had his wife died.

Throughout the book there are many reasons to laugh and reflect. $A$ Hard Chance describes the stormy weather and also the irony of life. Before the accident, Tom and Melissa Gallant were facing a crumbling marriage and looming divorce.

Readers on both sides of the long, tough process of treatment and rehabilitation of a head trauma and brain injury will appreciate this book. Perhaps Gallant's most impressive point: it needs the will and spirit, and the love, really, of the two people closest to the experience.

\section{Sean Flinn}

Freelance Writer

Halifax, NS

A Hard Chance - Sailing into the Heart of Love was awarded the Margaret and John Savage First Book Award at the 2006 Atlantic Book Awards. The award is funded by The John and Margaret Savage Medical Humanities Endowment Award, which is administered by Dalhousie University's Department of Medical Humanities. 